Doi: 10.5212/Uniletras.v.37i2.0005

\title{
A NARRATIVA NA SOCIEDADE MIDIÁTICA: O ACESSO À FICÇÃO POR MEIO DA TELENOVELA
}

\section{THE NARRATIVE IN MEDIA SOCIETY: ACCESS TO FICTION BY SOAP OPERA}

\author{
Francisco Claudio Alves Marques" \\ Rondinele Aparecido Ribeiro**
}

Resumo: É clássica a definição de que o homem se constitui por meio da linguagem e por meio dela se insere socialmente. Assim posto, constata-se a extrema dependência que as mídias exercem no indivíduo no cenário pós-moderno para fins de entretenimento. É inegável que, atualmente, a ficção seriada ocupa um papel de destaque na contemporaneidade, com maior relevância para o gênero telenovela, que se constitui não apenas um meio de entretenimento, mas também um processo de interação e de representação no cotidiano do telespectador. Dessa forma, o presente artigo pretende tecer considerações acerca da constituição desse gênero discursivo televisivo. Acredita-se que este trabalho seja importante em razão das especificidades do gênero discursivo em debate, o qual tem status de híbrido pelo fato de ter sua gênese na literatura e nas manifestações massivas.

Palavras-chave: Telenovela; Ficção; Folhetim.

AвSTRACT: It's classic definition that man is constituted through language and through it fits socially. So put, there has been extreme dependence that the media play in individual post-modern setting for entertainment purposes. It is undeniable that, currently, serial fiction occupies a prominent role in contemporary society, with greater relevance to the telenovela genre, which is not only a means of entertainment, but also a process of interaction and representation in the viewer's everyday life. Thus, this article aims to make considerations about the constitution of this televised speech genre. This work is believed to be important for the particularities of the discursive gender debate, which has hybrid status by having its genesis in literature and the mass demonstrations.

KEYwords: Soap opera; Fiction; Serial.

\footnotetext{
"Doutor pela Universidade de São Paulo. Professor no Departamento de Letras Modernas da UNESP - Assis. Email: fransclau@gmail.com.

" Docente da Faculdade do Norte Pioneiro - FANORPI/UNIESP. Especialista em Cultura, Literatura Brasileira e Língua Portuguesa. Licenciado em Letras/Literatura pela UENP (2011). Graduando em Direito. Membro do GP Cultura Popular e Tradição Oral: Vertentes (UNESP-ASSIS). Email: rondinele-ribeiro@bol.com.br.
} 


\section{INTRODUÇÃO}

A narrativa é uma necessidade atávica do ser humano. Sempre que se volta para a tarefa de tecer considerações acerca de sua gênese, acaba-se voltando para o conceito de comunicação, grande responsável por garantir o ideal de perpetuação das narrativas. Fazendo-se uma constatação muito corriqueira no meio acadêmico, chega-se à conclusão de que o hábito de contar histórias revela uma atitude que existe desde o momento em que o homem descobriu sua capacidade de articular signos e de se comunicar. Como assevera Mauro Alencar (2002, p. 41), falar sobre a narrativa é falar sobre a origem da história do homem.

Enquanto necessidade inerente ao homem, a narrativa confere significação às ações humanas, sendo responsável por mediar as ações da humanidade no mundo. Enquanto modalidade de intercambiar experiências, é lícito afirmar que a narrativa ocupa o posto de modalidade discursiva híbrida à medida que se vale dos recursos verbais, icônicos ou mistos. Utilizando pressupostos de Barthes (1971, p. 21), chega-se à conclusão de que a narrativa está presente em todos os tempos, em todos os lugares, em todas as sociedades. Salvatore D'Onofrio (1995), ao conceituá-la, observa que "todo discurso que nos apresenta uma história como se fosse real, constituído por uma pluralidade de personagens, cujos episódios de vida se entrelaçam num tempo e num espaço determinado, é uma narrativa" (D' ONOFRIO, 1995, p. 53-4).

$\mathrm{Na}$ contemporaneidade, um fato que acaba despertando a atenção de uma parcela significativa de pesquisadores remonta às questões envolvendo narrativa e meios audiovisuais, já que é senso comum que se vive em uma era marcada pela dependência de mídias para fins de entretenimento e acesso à ficção. Assim, recorremos aos postulados de Roger Silverstone para tecer algumas considerações acerca dessa constatação. $\mathrm{O}$ teórico considera a impossibilidade de escaparmos da mídia pelo fato de se ter criado uma dependência desse formato. Nas palavras do autor, "nossa mídia é onipresente, diária, uma dimensão essencial de nossa experiência contemporânea" (SILVERSTONE, 2002, p. 12).

Para fundamentar ainda mais a discussão, trazemos à baila os pressupostos do teórico Douglas Kellner (2001), que sustenta o fato de as mídias serem uma forma dominante na cultura contemporânea, fornecendo um amplo material para a formação de identidades. Nas palavras do autor, "Há uma cultura veiculada pela mídia cujas imagens, sons e espetáculos ajudam a urdir o tecido da vida cotidiana, dominando o tempo de lazer, modelando opiniões políticas e comportamentos sociais" (KELLNER, 2001, p. 9).

Assim, nessa sociedade midiatizada, não se pode relegar o papel de um dos grandes meios de comunicação mais influentes já inventados: a televisão. Sabe-se que no Brasil esse meio de comunicação redimensionou a promoção de entretenimento para a sociedade, notabilizando-se como veículo de comunicação que mais atinge os lares brasileiros, ditando regras, valores e formas de conduta. Nas palavras de Maria T. Fraga Rocco (1994, p. 55), "o veículo se tornou parte integrante, se não integradora, do cotidiano 
de todas as pessoas em praticamente todo o mundo". Segundo Dominique Wolton (1996), a televisão "é um laço social indispensável numa sociedade onde os indivíduos ficam frequentemente isolados e, às vezes, solitários" (WOLTON, 1996, p. 16). De fato, o advento da televisão foi responsável pela ruptura de fronteiras jamais vistas, o que fez esse objeto se tornar o responsável pelo meio formativo e informativo da sociedade, fato que nos obriga a refletir sobre o poder que tal veículo midiático exerce na "reeducação" da sociedade e na consequente formação de um novo "horizonte de expectativas".

A respeito dessa questão, Néstor G. Canclini (2006) coloca em discussão a crença generalizada, difundida entre os críticos dos meios de comunicação de massa, na capacidade ilimitada da mídia para estabelecer os roteiros do comportamento social e distrair as massas de sua realidade. Apoiado em estudos que, a partir dos anos de 1970, começam a questionar o popular como entidade subordinada, passiva e reflexa, e ainda nas concepções pós-foucaultianas de poder, que preferem pensá-lo como relação social disseminada, Canclini tece algumas considerações que acabam colocando em xeque a ideia de que veículos como a televisão exercem um poder absoluto no telespectador, fazendo-o, sobretudo, por levar em conta a coparticipação dos setores populares nessas relações de força. Tais relações, segundo o autor, "se constroem simultaneamente na produção e no consumo, nas famílias e nos indivíduos, na fábrica e no sindicato, nas cúpulas partidárias e nos órgãos de base, nos meios massivos e nas estruturas de recepção que acolhem e ressemantizam suas mensagens" (CANCLINI, 2006, p. 261-2).

Essas observações de Canclini (2006) acabam por minar aquela ideia equivocada de que determinados produtos culturais impostos pelas classes dominantes são recebidos pelo popular passiva e irrefletidamente, de modo que este passaria apenas a reproduzi-los. De acordo com Canclini, "as tecnologias comunicativas e a reorganização industrial da cultura não substituem as tradições nem massificam homogeneamente, mas transformam as condições de obtenção e renovação do saber e da sensibilidade". O que tais tecnologias propõem, segundo o autor, são "outros códigos de identificação das experiências, de decifração de seus significados e modos de compartilhá-lo", reorganizando, de certo modo, "as relações de dramatização e credibilidade com o real", no entanto, complementa, "ignoramos quase tudo sobre o modo como os setores populares assumem essa transformação" (CANCLINI, 2006, p. 262-3). O que se sabe, de fato, é que o grande sucesso dos meios eletrônicos de comunicação, como a televisão, se deve, sobretudo, ao fato de que estes veículos mostram notável continuidade com as culturas populares tradicionais, na medida em que ambos são "teatralizações imaginárias do social” (CANCLINI, 2006, p. 258-9).

Enquanto suporte formativo e informativo, a televisão apresenta vários programas submetidos a formatos específicos. O estudioso Arlindo Machado, que se preocupou em estudar os produtos televisivos, divide os gêneros televisuais em sete: as formas fundadas no diálogo, as narrativas seriadas, 
o telejornal, as transmissões ao vivo, a poesia televisual, o videoclipe e outras formas musicais. $\mathrm{O}$ autor destaca ainda três formas principais de narrativas seriadas: os teledramas, as telenovelas e as séries e minisséries. Sobre tais modalidades, sui generis, diz Machado (2000):

Esse tipo de construção se diz teleológico, pois ele se resume fundamentalmente num (ou mais) conflito(s) básico(s), que estabelece logo de início um desequilíbrio estrutural, e toda evolução posterior dos acontecimentos consiste num empenho em restabelecer o equilíbrio perdido, objetivo que, em geral, só se atinge nos capítulos finais (MACHADO, 2000, p. 84).

Como se percebe, o produto ficcional mais promissor da televisão é a telenovela, que responde por ser a grande promotora de ficção na contemporaneidade, sendo lícito atribuir-lhe a denominação de "folhetim eletrônico". Ao tratar das peculiaridades das narrativas televisivas, Maria Aparecida Baccega (2003) preconiza que a televisão e a telenovela caracterizam-se pela linguagem narrativa. A autora salienta que esse meio de comunicação apresenta-se como uma "pessoa":

É esse seu jeito de «contar histórias» que faz com que ela [a televisão] atue como se fosse uma "pessoa" de nossas relações. Ela sempre narra "casos" que aconteceram aqui e acolá, construindo uma história sem fim (como as Mil e Uma Noites?), caracterizando "uma conversação em andamento dentro de uma comunidade local, nacional ou internacional onde as últimas notícias, dramas, esportes e modas são nada mais do que o último episódio de uma história cultural contínua" (BACCEGA, 2003, p. 9).

Pode-se inferir, a partir dos postulados de Baccega, que a televisão cumpre um novo papel de legar e promover o acesso à ficção, uma vez que se consubstancia como um veículo capaz de materializar as referências histórico-sociais do indivíduo e catapultá-las em suas narrativas repletas de significados e símbolos que acabam por envolver o ser humano na urdidura de seu amargo dia, reatualizando mitos a partir de aspectos corriqueiros, fazendo com que os telespectadores encontrem um verdadeiro significado para sua existência vital.

Apoiado em Umberto Eco, Flávio Aguiar (2003) observa que elementos como a TV, assim como a pintura, a fotografia, a escultura e a arquitetura, "são criadores de mitos, no sentido aristotélico da palavra, isto é, de fabulações que engendram a possibilidade do reconhecimento da situação presente dos destinatários em relação aos parâmetros da cultura de que fazem parte" (AGUIAR, 2003, p. 123). Embora a televisão tenha emprestado seus primeiros temas da literatura, cabe ressaltar que, tanto o cinema quanto a televisão, vão se distanciar do texto literário pelo fato de que, neste, "os estímulos emotivos vêm após os leitores atravessarem uma verdadeira cortina de operações semânticas e sintáticas guiadas por signos, materializados em palavras e organizados em conceitos", enquanto que naqueles, "a presença da imagem virtual desperta ações imediatas, incluindo-se as 
fisiológicas, com risos, lágrimas, descargas de adrenalina e outras" (AGUIAR, 2003, p. 120).

Depois de estabelecidas algumas considerações acerca da narrativa na contemporaneidade, apresentaremos algumas considerações acerca do gênero televisivo de maior destaque, a telenovela. Interessa-nos, no tópico seguinte, traçar um breve panorama acerca da gênese deste gênero bem como apontar sua função na sociedade atual.

\section{ORIGENS DA TELENOVELA}

Não restam dúvidas de que a telenovela tem sua gênese no romance de folhetim, do melodrama e das radionovelas. Seu fundamento, de acordo com o pesquisador Roberto Sadek (2008), remonta a uma necessidade intrínseca ao ser humano: o velho gosto pela narração, podendo, por esse motivo, ser incluída, pelo menos em parte, na velha tradição de contar e de ouvir histórias, uma vez que a telenovela "tem um passado significativo, que começa com a primeira narrativa" (SADEK, 2008, p. 17). A grande diferença consiste no fato de que, como na velha tradição oral, em que o ouvinte interagia com o contador de histórias, o telespectador não estabelece uma interação face a face, no sentido tradicional do termo, com $\mathrm{o}$ artefato televisivo.

Constituindo-se um gênero da teledramaturgia, a telenovela está presente no país desde a implantação da televisão, contudo trata-se de um produto considerado menos nobre, sobretudo, pela existência do teleteatro, que preconizava a encenação de textos literários. Acerca desse caráter pouco industrial, valem as asserções de Sadek (2008):

O começo da TV no Brasil foi improvisado. Ela foi trazida praticamente num rompante na década de 1950, e, como não havia gente especializada nesse trabalho, os técnicos do rádio foram requisitados para fazer os primeiros programas da TV. Os profissionais da geração seguinte aprenderam com os colegas mais velhos, criando uma cadeia que passava o conhecimento do mestre para o aprendiz, como nas sociedades de tradição oral, pré-escrita (SADEK, 2008, p. 12).

A telenovela, como já afirmado, está presente no país desde a implantação da televisão, todavia, enquanto formato seriado, o país já contava com uma tradição semelhante legada pelas radionovelas. Ao longo dos anos, constata-se que esse produto de mídia foi mudando seu formato. Vale lembrar que, nos seus primórdios, tais produções eram visivelmente marcadas pela improvisação, uma vez que ainda não contava com um aparato técnico responsável por alçá-la ao status profissional. Como explica Sadek (2008), imperava nessas produções o caráter de improviso, uma vez que nessa fase inicial os responsáveis pela teledramaturgia eram oriundos do rádio, tendo, portanto, que aprender a nova linguagem que vinha sendo criada pela televisão.

Quando chegaram ao país, importadas de Cuba e da Argentina, países pioneiros nesse gênero ficcional onde a 
tradição melodramática imperava, as telenovelas brasileiras herdaram a fórmula já experimentada e consagrada nos demais países latino-americanos.

Mauro Alencar (2002) observa que "O melodrama é um gênero em que os diálogos são entremeados de música. Humano, imaginoso e vivaz, cria intrigas e paixões com habilidade e requer uma completa identificação entre o espectador e personagem" (ALENCAR 2002, p. 49). Nesse gênero as personagens são criadas de modo a despertarem um sentimento de compaixão no público. Dessa for$\mathrm{ma}$, as representações de pessoas boas, perversas, fortes, fracas e sem muita densidade psicológica, são amplamente empregadas.

Se quisermos estabelecer um marco para o surgimento do melodrama, devemos levar em consideração a observação de Martín-Barbero (2003), segundo o qual o surgimento do gênero remonta aos anos de 1790 na Inglaterra e na França. O melodrama consistia numa espécie de teatro, cujos espetáculos, de cunho popular, colocavam em cena temas relacionados aos novos padrões de comportamento que vigoravam na época. Martín-Barbero comenta que o teatro mantinha uma espécie de vínculo com a sociedade, uma vez que grande parcela da população passou a se identificar com os personagens e com os enredos encenados (MARTÍN-BARBERO, 2003, p. 169-170).

Não se pode, contudo, falar acerca de telenovela no Brasil sem falar de Glória Magadan, novelista de suma importância para a história da telenovela latino-americana, que veio residir no país em 1964 na condição de exilada. Aqui, foi responsável por dirigir produções exibidas pela TV Tupi. A mencionada autora tornou-se ícone do símbolo melodramático no início da telenovela no Brasil. Sua estreia em novelas se deu no rádio, em 1940, com o trabalho Cuando se quiere um inimigo. Depois dessa produção, a novelista passou a integrar o Departamento de Publicidade de Telenovela no continente americano.

Magadan adotava a concepção de que as produções novelísticas deveriam funcionar como "alívio das tensões do dia-a-dia", de modo que suas produções, em razão disso, foram taxadas de alienantes. Anos depois, com a inauguração da Rede Globo, a autora foi contratada para escrever telenovelas para o horário considerado nobre, o das 20 horas. Como marca característica de suas produções, predominava um enredo bastante artificial marcado pelo predomínio de cenários exóticos e bastante distanciados da realidade nacional. Sobre esse aspecto, observa Alencar (2003):

Na década de 1960, porém, a realidade brasileira ainda não figurava nas histórias, que eram absurdas e bizarras, inverossímeis. O mundo televisivo era povoado de histórias exóticas, personagens bons e maus, maniqueísmo sempre presente (ALENCAR, 2003, p. 89).

Assim, é possível concluir que, embora tenha operado uma ligeira evolução no aspecto linguístico, no que tange às temáticas, nada se alterou, haja vista que a autora era adepta dos moldes melodramáticos, que tanto logravam êxito nos demais países latino-americanos onde predominavam enredos inverossímeis representados por 
personagens fortemente estereotipados. Dessa forma, prevalecia nos teledramas aqui produzidos o tom artificial, haja vista que não estabeleciam nenhuma relação direta com a realidade política e social brasileira.

Tal fato prevalece até a saída da autora da Rede Globo, em 1969. A partir daí, o distanciamento da realidade social que predominava nas telenovelas anteriores passa a ser minimizado, de modo que a Rede Globo passa a investir na teledramaturgia com vistas a formar um núcleo profissional e a torná-la um "hábito" entre os brasileiros, como salienta Alencar (2003):

Com a saída da novelista Glória Magadan em 1969, a TV Globo forma um núcleo profissional, investe em atores, autores e equipamentos. É uma revolução. Uma revolução que definiu estruturas que levaram a telenovela a firmar-se como fenômeno, um hábito, um condicionamento tão necessário ao brasileiro quanto escovar os dentes (ALENCAR, 2003, p. 89).

Com a saída de Glória Magadan da Rede Globo, a telenovela passa por algumas mudanças estruturais bastante significativas. Sílvia Borelli (2001) elenca as principais mudanças pelas quais as telenovelas passaram, apontando, inclusive, para a inserção do videoteipe, técnica que tornou possível o armazenamento, a correção e a exibição das imagens; para a adoção de câmeras mais leves, que possibilitaram a gravação de cenas externas e não apenas em estúdios; para a inserção da cor, que alterou significativamente o formato do gênero e, finalmente, para a criação de departamentos responsáveis por profissionalizar o gênero (BORELLI, 2001, p. 33).

Ao tecer considerações acerca do espaço da telenovela na produção contemporânea, Borelli constata que, nas décadas de $1950 \mathrm{e}$ 1960, a produção de novelas era norteada pelas seguintes características: fronteiras ainda difusas, uma vez que a televisão não contava com uma linguagem própria que a distinguisse do formato literário, teatral ou cinematográfico; o caráter melodramático das narrativas herdado das radionovelas. Segundo a autora, imperava, "neste contexto, os conflitos e simbioses processados entre os campos da literatura, imprensa, rádio, teatro, articulados, na TV, ao redor de um importante mecanismo de reprodução das indústrias culturais, a serialização". Outra característica apontada alude à forte improvisação técnica a que o gênero se subordinava, uma vez que ainda não contava com a definição dos diferentes papéis na produção, tais como roteiristas, diretores, figurinistas, cenógrafos etc. (BORELLI, 2001, p. 32).

Insistindo nas características das produções do referido gênero, Borelli lembra também da migração de autores, diretores e atores do rádio, do teatro e do cinema para a televisão com o intuito de enriquecer e emprestar ao veículo um perfil com características mais profissionais. No que tange às temáticas, pode-se falar que, nessa fase inicial, grande parte dos roteiros era adaptada de obras literárias. Tal estratégia era empregada para legitimar um gênero incipiente, que ainda não contava com um formato profissional definido (BORELLI, 2001, p. 32). 
Para Sadek (2008, p. 35), a partir da adoção do videoteipe nos anos de 1960, ocorreu a operacionalização do gênero e as telenovelas passaram a ser mais viáveis. Em 1963, a tevê Excelsior importou da Argentina o modelo de telenovela que impera até hoje no Brasil, as novelas diárias. A telenovela 25499 Ocupado, no Brasil denominou-se 0597 Dá ocupado, tendo sido a primeira do gênero a ser exibida diariamente no país. "Teleencenada" pela TV Excelsior, em São Paulo, no horário das 19 horas, a trama foi exibida de julho a setembro de 1963, colocando em cena os atores Tarcísio Meira e Glória Menezes, no papel de protagonistas.

"A ideia de transmissão diária dos capítulos nasceu de uma viagem de Edson Leite, superintendente da TV Excelsior, à Argentina, onde viu novelas exibidas diariamente, sempre no mesmo horário. Ao voltar, comprou os direitos da novela" (TÁVOLA, 1996, p. 86). Dessa forma, como pontua Alencar (2003, p.20), "mais de uma década depois, as histórias, antes contadas duas ou três vezes por semana, passaram a ser diárias".

A trama tinha como ponto de partida um tema bastante caro aos folhetins: um amor impossível. Uma ligação telefônica feita por Emily, personagem interpretada por Glória Menezes, uma presidiária, que trabalhava como telefonista num presídio, cai por engano no escritório do advogado Larry, interpretado por Tarcísio Meira, que acaba se apaixonando pela voz misteriosa sem, contudo, conhecer a real condição da amada. Como é possível perceber, a estrutura é extremamente romântica, prevalecendo elementos ainda muito próximos da pioneira produção folhetinesca fundada na idealização, no primado do sentimento e na impossibilidade da relação amorosa.

Ao que tudo indica, o formato de exibição diário da telenovela foi fundamental para se fisgar audiências por meio de uma programação específica que visava atrair um público mais amplo e diversificado à medida que a televisão ia paulatinamente entrando nos lares de todo o país. Essa estratégia, empregada nos anos 60, iria se consolidar na década posterior.

Nas palavras de Sadek (2008, p. 35), "as telenovelas passaram a trabalhar segundo a reação de audiência, alongando ou encurtando as histórias conforme o interesse do público e dos anunciantes". Para ilustrar o comentário de Sadek, podemos exemplificar com a telenovela Redenção, produzida entre os anos de 1966 e 1968. A trama, exibida pela TV Excelsior, teve 596 capítulos marcados por características fortemente presentes no melodrama, conforme já exposto, gênero originário da França, vigente no século XIX e que gozava de forte aceitação junto ao público, o que propiciou o alastramento do drama romântico.

Vale ressaltar que o formato de exibição diário foi responsável por incutir a fidelização de um público, sendo responsável também pelos primórdios da tão comentada guerra de audiência no meio televisivo.

\section{A SERIALIZAÇÃo DA TELENOVELA No BRASIL}

Em uma abordagem que preza mais a questão da narratividade, pode-se dizer que o hábito de assistir a histórias diárias passa 
a cumprir a mesma função da narrativa folhetinesca na sociedade brasileira do século XIX, ou seja, promover acesso à ficção. No que tange à conquista de um público, Sadek (2008) assevera que o fato de ocorrer a serialização de histórias na televisão é fundamental para a manutenção do público:

$\mathrm{O}$ espectador disperso e inquieto tem sua atenção solicitada pela TV, que concorre com os demais atrativos do ambiente e da vida real. O seriado permite ao público acompanhar a história mesmo entre lapsos de atenção e se familiarizar com os personagens de modo que continue a conviver com eles, mesmo quando perde um capítulo ou parte dele (SADEK, 2008, p. 33).

Foi com a estréia de O Direito de Nascer, em fins do ano de 1964, que o formato diário logrou êxito. A trama exibida ao longo de pouco mais de sete meses encantou o público das duas principais cidades do país. Adaptada para o Brasil por Thalma de Oliveira e Teixeira Filho, a telenovela foi escrita originalmente pelo cubano Felix Caignet, tendo sido transmitida pela rádio de Havana, em 1946. O enredo conservava a mesma estrutura das narrativas românticas. A trama se passa numa sociedade extremamente conservadora. Uma mãe solteira tem um filho ameaçado pelo avô, que não aceita a criança bastarda. A mãe entra no convento e a criança é criada bem distante pela empregada da família, a mamãe Dolores, personagem que cria e educa o garoto cujo nome é Alberto.

Se com a telenovela O Direito de Nascer, o formato diário logrou êxito no Brasil, grandes alterações ocorreram a partir da exibição de Beto Rockfeller, novela que consagrou o escritor Bráulio Pedroso. A referida novela está entre as tramas que ajudaram a inaugurar a chamada era das telenovelas "inteligentes" - "inteligência” não como critério de algum tipo de faculdade intelectual, mas como critério de valor para setores razoavelmente cultos da sociedade (KEHL, 1980, p. 50). Exibida entre 1968 e 1969, a trama é considerada revolucionária por empregar como protagonista um anti-herói, um verdadeiro trapaceiro que vendia sapatos em um bairro popular e desejava ingressar no mundo dos ricos. Para Sadek (2008), essa telenovela é a primeira considerada moderna, com temática bastante atual, sendo responsável por atrair o público masculino, até então, ausente das telenovelas, já que tais produções eram, em sua essência, melodramáticas. Em sua tessitura, Beto Rockfeller inovou empregando diálogos marcados pela coloquialidade e pelo emprego de gírias: "A encenação era naturalista. Espectadores ricos e pobres ficaram encantados com as manobras de Beto para participar de um mundo que não era o seu" (SADEK, 2008, p. 37).

Artur da Távola (1996) também explicou o sucesso da novela. Para ele, com essa telenovela, conseguiu-se superar o esticamento artificial bem como mudanças no horário. A obra de Bráulio Pedroso, na visão do teórico, serviu para apontar "o caminho para a telenovela: a atualização dos temas, o cotidiano da população, impasses e esperanças da sociedade real" (TÁVOLA, 1996, p. 93).

Cabe ressaltar que os experimentos e inovações colocadas em prática pela TV Tupi concorreram para uma 
considerável renovação na teledramaturgia brasileira. Contudo, foi com a Rede Globo de Comunicação que o gênero se consolidou e industrializou-se, já que foi essa emissora quem conferiu acabamento às telenovelas, fazendo delas um forte produto cultural por empregar em sua fórmula a adoção de uma linguagem coloquial bem como cenários urbanos contemporâneos, superando o exotismo que imperava até então no gênero. Nesse período, "A Globo responde na atualidade pelo abrasileiramento total da telenovela e por sua transformação em produto de consumo em território nacional e internacional" (ALENCAR, 2003, p. 53) e é aqui, segundo ainda Alencar, que vai ocorrer uma revolução no gênero, a chamada revolução industrial da ficção brasileira. A esse respeito, valem as asserções de Távola (1996):

A década de 70 na televisão brasileira é conhecida como a da profissionalização, que engendrou a expansão impressionante do novo meio de comunicação. Os avanços tecnológicos foram igualmente fundamentais para a racionalização da produção. O videoteipe, por exemplo, revolucionou as técnicas de produção e permitiu o começo de uma política interestadual da tevê, germe da estratégia de programação nacional afinal dominante (TÁVOLA, 1996, p. 90).

É importante lembrar que as empresas de higiene e dentifrícios como ColgatePalmolive, Gessy Lever e Kolynos eram as grandes produtoras de telenovelas, que usaram o gênero como uma fórmula consagrada para a divulgação de seus produtos. A partir da revolução imposta pela ascensão da
Rede Globo de Comunicação, "as telenovelas passaram a trabalhar segundo a reação de audiência, alongando ou encurtando as histórias conforme o interesse do público e dos anunciantes" (SADEK, 2008, p. 35).

O fato é que na década de 1970, a Rede Globo tinha que realizar verdadeiros malabarismos para ajustar-se às exigências do público, atender os anunciantes e ainda adequar sua programação à chamada política de integração nacional instaurada pelo governo federal, o que fica bastante evidente no pronunciamento do então Ministro das Comunicações em dezembro de 1973: "a Globo foi a única emissora de televisão que cumpriu até então as exigências do Governo Federal - 'a transmissão eletrônica de recreação, informação e educação nas mãos da iniciativa privada, alicerçada numa sólida estrutura de empresa moderna" (apud KEHL, 1980, p.13). Tratava-se, portanto, de (re) educar o telespectador por meio de um discurso pensado e elaborado pela ideologia dominante. No entanto, pensando nas palavras de Canclini (2006), sobre a não passividade das camadas populares, nos perguntamos até que ponto tais sugestões culturais veiculadas pela televisão, a serviço do governo, foram irrefletidamente recebidas pelo telespectador. Nessa mesma direção seguem as observações de Maria Rita Kehl (1980), reunidas no sugestivo tópico "A máquina de sugar cérebros":

Quando se pensa na televisão como "sugadora de cérebros" logo se imagina a imagem criada pelo Pasquim, do monstro diabólico esvaziando de qualquer conteúdo inteligente, como um aspirador, a cabecinha passiva de seus espectadores. Não gosto da imagem: 
nem a televisão é tão poderosa assim, nem as cabeças do público tão passivas, nem o processo pelo qual uma e outra interagem equivale a uma mera relação sugadora (KEHL, 1980, p. 17).

No entanto, complementa Kehl (1980), "Para manter seu público atento, a televisão precisa saber preencher lacunas de insatisfação, dar nome ao que ainda não foi não foi dito, dar forma ao inconsciente coletivo, ordenar o caos das chamadas 'manifestações espontâneas' conferindo-lhes um significado único antes que outro aventureiro lance mão da tarefa de compreendê-las" (KEHL, 1980, p. 17). Na década de 1970, quando a televisão invade dezenove milhões de lares brasileiros, a Rede Globo sai na frente, principalmente, pelo fato de ter percebido, antes das outras emissoras, que um programa de televisão pode tratar de conteúdos mais ousados, mais atuais, mais "realistas" e, sobretudo, por fazê-lo transformando tudo em objeto de distração, segundo Kehl, "aquilo que o público consome distraído, entre um comercial e outro, entre a sobremesa e o cafezinho, entre o noticiário esportivo e as chamadas para a próxima novela" (KEHL, 1980, p. 23).

E quanto ao tratamento dado aos problemas sociais reais, tendo em vista que a televisão brasileira ingressava na fase da abertura política do país, Kehl observa que os ideólogos da Globo perceberam que, aos invés de omitir os problemas e exigências da realidade social, seria melhor encampá-los sob sua tutela. Desse modo, as reivindicações por "mais realismo", "menos fantasia”, "menos ilusão" e outras oriundas de setores mais avançados do público e dos próprios críticos, serviram de orientação à estratégia de programação da emissora que começou a priorizar, ao nível do senso comum, a realidade brasileira. Nem mesmo os fenômenos criados pelas vanguardas da sociedade, como a liberação sexual e os movimentos ecológicos anticonsumistas foram omitidos, temas que, segundo a autora, consistem em excelentes chamarizes para a curiosidade das massas menos informadas e marginalizadas se abordados com o devido cuidado para que tais massas não os considerem "incompreensíveis" (KEHL, 1980, p. 27).

E em que medida a televisão, por meio da telenovela, conseguiu reelaborar certos aspectos da realidade e do cotidiano do espectador? Qual a medida do sucesso obtido por meio de tais estratégias? Qual ou quais realidades passaram a ser representadas na tela? Tínhamos uma realidade política e social, embutida nos problemas e mazelas do povo em geral, na divisão de classes, e uma geográfica e cultural, centrada na existência de um público, distribuído em um país de dimensões continentais, acostumado, muitas vezes, à leitura do folhetim, do cordel; a ouvir o rádio; a contar e escutar histórias. Segundo Kehl (1980), as grandes bandeiras dos autores e diretores de telenovelas da década de 70 passam a ser "Realismo", "realidade brasileira", "vida real". Esses profissionais

[...] encontram na imitação das aparências da realidade empírica um elemento de sucesso, favorecendo ainda mais a identificação emocional dos espectadores com a problemática vivida e sofrida pelos personagens principais. Fala-se em "doses de realismo", "nível de realidade", "graus de aproximação 
com o real"... [...] com tão pedagógicas pretensões [...] trata-se de ensinar ao espectador das telenovelas como é a sua realidade... (KEHL, 1980, p. 52).

Santuza Ribeiro e Isaura Botelho afirmam que, nessa época, a realidade brasileira vai sendo veiculada em doses homeopáticas, e empregam falas de Homero Icaza Sanchez, um dos diretores da Globo, à época, e de Paulo Afonso Grisolli para ilustrar o fenômeno que, depois de selecionar um tipo de público-alvo, se limitava a determinar linhas de programação de acordo com o horário. Homero, dirigindo-se a uma senhora, afirma:

Se a senhora assistir todos os jornais da Globo, se dará conta de que muita notícia aparece em outros horários. Então, por exemplo, o horário das 7 horas é um horário pouco assistido pelo subúrbio. Então, se o subúrbio assiste o noticiário das greves às 7 horas, diz assim: “_Veja só! Crime, quebra-quebra, porrada, o diabo a quatro .... Então, há uma distribuição da notícia. Eu já ouvi gente dizer: "_Puxa, todo mundo entrevista Brizola e você não entrevista”. Ora, a nossa entrevista com o Brizola foi de mais de uma hora, mas apareceu no ultimo jornal e pouca gente viu" (apud RIBEIRO \& BOTELHO, 1980, p. 88).

E Paulo Afonso Grisolli:

De repente, às 10 da noite, a televisão começa a ficar classificada. Não é um horário popular por natureza. O povo vai dormir cedo para trabalhar de manhã. E começa a ser um horário mais intelectualizado, mais sofisticado, e começa a permitir, na medida em que esse mercado de consumo vai sendo gratificado pelo nível de debate, da temática, da elaboração, que se vá ficando mais aficionado. E vai consumindo televisão e vai se tornando o novo mercado consumidor pelo seriado (apud RIBEIRO \& BOTELHO, 1980, p. 88).

Além das questões relacionadas com a disponibilidade de tempo para permanecer diante da tela e com a posição social de cada espectador, já acenadas, a televisão deve preocupar-se ainda, segundo MartínBarbero, em eleger dois intermediários fundamentais que facilitem o trânsito entre a realidade cotidiana e o espetáculo ficcional. Trata-se do apresentador-animador, que interpela as famílias por meio de seu tom coloquial e da simulação de um diálogo que não se restringe a um arremedo do clima “familiar". Martín-Barbero (2003) suspeita que "a predominância do verbal na televisão se inscreve na necessidade de subordinar a lógica visual à lógica do contato, dado que é esta que articula o discurso televisivo sobre o eixo da relação estreita e a preeminência da palavra em culturas tão fortemente orais" (MARTÍN-BARBERO, 2003, p. 306).

Outra abordagem que trata da produção de efeitos do "real" pela televisão vai gravitar em torno daquilo que Martín-Barbero chamou de "magia do ver", efeito dominado por "uma proximidade construída mediante uma montagem que não é expressiva, e sim funcional, sustentada na base da 'gravação ao vivo', real ou simulada”. A sensação de proximidade dos personagens e dos acontecimentos, geradas no espectador, viabiliza um "discurso que familiariza tudo, torna 'próximo' até o que houver de mais remoto 
e assim se faz incapaz de enfrentar até os preconceitos mais 'familiares", construindo uma "interpelação que fala às pessoas a partir dos dispositivos que dão forma a uma cotidianidade familiar, que não é apenas subproduto da pobreza e das artimanhas da ideologia, mas também espaço de algumas formas de relação primordial" (MARTÍN-BARBERO, 2003, p. 306).

A serialização também faz parte das estratégias de se produzir algo que gere no espectador a sensação de realidade. Embora o tempo do seriado fale a língua do sistema produtivo, a da estandardização, MartínBarbero (2003) observa que por trás dele também se podem ouvir outras linguagens: "a do conto popular, a canção com refrão, a narrativa aventuresca, aquela serialidade 'própria de uma estética em que o reconhecimento embasa uma parte importante do prazer éé, em consequência, norma de valores dos bens simbólicos"' (MARTÍN-BARBERO, 2003, p. 308). Outra categoria televisiva apontada por Martín-Barbero (2003), o melodrama, também ajuda a engrossar a fileira dos elementos e estratégias empregadas pela televisão para emprestar às suas produções um tom de realidade e uma sensação de proximidade com o cotidiano do espectador:

[...] o melodrama continua a constituir um terreno fértil para o estudo da não-contemporaneidade e das mestiçagens de que estamos feitos. Como nas praças de mercado, no melodrama está tudo misturado, as estruturas sociais com as do sentimento, muito do que somos-machistas, fatalistas, supersticiosos - e do que sonhamos ser, o roubo da identidade, a nostalgia e a raiva. [...] o melodrama explora nestas terras um profundo filão de nosso imaginário coletivo, e não existe acesso à memória histórica nem projeção possível sobre o futuro que não passe pelo imaginário (MARTÍN-BARBERO, 2003, p. 316).

Enfim, na década de 70, para ficarmos ainda com a questão do tempo e da serialização na TV, os programas e novelas eram moldados de forma a atender as necessidades do público, de acordo com sua disponibilidade de tempo, posição social e intelectual, como nos faz entender Daniel Filho, um dos diretores da Globo, à época: para o horário das sete a grande comédia romântica, do tipo Doris Day, era a mais indicada, mas aos poucos, relata Daniel, "passamos a colocar dados brasileiros, locais brasileiros, som brasileiro... é importante que a novela contenha um nível de verdade, de cotidiano, e um nível de fantasia. Na continuação ele explica que, para o horário das oito, novelesco e "pseudamente inteligente", é preciso que haja sempre um grande mistério. A novela deve apresentar personagens de várias faixas etárias, para identificação de um público mais amplo possível, mas com uma problemática mais feminina do que masculina. É necessário que contemple todas as classes sociais e principalmente é imprescindível que haja ascensão social. A novela deve lançar atores novos ao lado de atores consagrados, e conter sempre uma novidade, um assunto emergente no momento, uma moda qualquer que não é a televisão quem cria mas é ela que difunde por todo o país, como aconteceu com as discotecas em Dancin' Days (apud KEHL, 1980, p. 53) 
Atualmente, as novelas que vão ao ar apresentam um cenário requintado, com locações e figurinos esplendorosos. O corpus narrativo é constituído de diálogos e os autores procuram elaborar suas tramas de modo a se tornarem cada vez mais próximas da realidade do público, que acaba se identificando com o enredo e se interessando em acompanhá-lo. Sadek (2008, p. 47) comenta que "as telenovelas sofreram mudanças e adaptações até chegarem ao formato com que se apresentam atualmente", passando a apresentar uma estrutura extremamente complexa do que aparenta, não tendo relacionamento algum com o cinema.

Mauro Alencar observa que a estrutura da telenovela atual é rígida, baseando-se em 45 minutos de ação, haja vista que "uma telenovela no Brasil chega a ter quarenta cenas por capítulo; no começo, não passavam de dez. Cada cena divide-se em tomadas, ou takes, que, por sua vez, dividem-se em planos" (ALENCAR, 2002, p. 62).

Uma telenovela apresenta um número elevado de personagens que figuram em várias tramas paralelas. Contudo, pode-se dizer que a evolução não é extremamente previsível. Basta observar que as tramas prediletas do público acabam sendo majoritariamente mais bem cuidadas e melhor elaboradas que as demais. Isso ocorre, porque a telenovela, sendo um gênero aberto e alterável, permite ao escritor moldá-la de acordo com as exigências da audiência.

Em se tratando do conjunto de produção audiovisual, vigora a partir da década de 1990, como postula Esther Hamburger, as chamadas "novelas-intervenção":
No final da década, a diversificação de opção sintomaticamente fortalece um estilo que pode ser denominado de "novela de intervenção", em detrimento de novelas "representação da nação". No Brasil contemporâneo talvez não seja mais possível situar um espaço policlassicista, geracional e geográfico de expressão da nacionalidade (HAMBURGER, 2005, p.122).

Outra característica que pode ser apontada nas telenovelas do período apontado, ou seja, a partir dos anos 90, é a incorporação exacerbada de temas relacionados à sensualidade, à temática das drogas e da infidelidade, à ficcionalização da violência. Vale ressaltar o emprego de uma linguagem nitidamente popularesca e carregada de gírias, bem como de temas antes proibidos na época da censura, ou até mesmo não encarado com bons olhos pelos telespectadores, nos permitindo inferir que a telenovela, na atualidade, tornou-se ainda mais representativa da nação, tendo inclusive, adotado um tom mais polêmico.

A partir dos anos 2000, tem-se observado uma gama de temas sendo retratada pela telenovela: a periferia, a traição, o drama familiar, enfim, temáticas sociais e psicológicas, filões constantemente explorados, o que ajuda ainda mais, movida por essa pretensa função social, a garantir ficção ao público.

\section{Considerações Finais}

Longe de esgotar a discussão sobre o gênero telenovela, artefato da cultura de massa renegado durante muito tempo no meio acadêmico, este artigo se propôs a tecer considerações relevantes acerca da constituição 
do gênero no Brasil. Enquanto produto de mídia, a telenovela é um dos produtos mais consumidos na atualidade e o que mais agrega valores à sociedade, constituindo-se um corpus privilegiado pelo fato de balizar questões ligadas à representação identitária do país, servindo também como um gênero que reflete as (re) configurações sociais, familiares, políticas e históricas.

"No Brasil, frequentemente mais da metade dos aparelhos de TV ligados sintonizam a mesma telenovela, que, em contato diário com os espectadores, lança modas, induz comportamentos, opina acerca de polêmicas, presta serviços e participa do cotidiano do país" (SADEK, 2008, p. 11).

Originária de tradições populares e massivas, tais como o romance de folhetim, radionovelas e soap opera, a telenovela constitui na atualidade um fenômeno representativo do país. Notabilizando como objeto de estudos acadêmicos, o gênero é alçado ao posto de verdadeira narrativa acerca do Brasil, desempenhando um espaço privilegiado para a discussão de temáticas sociais. Pode-se dizer que este gênero televisivo se constitui como um meio de apropriação de espaços e de saberes, já que, por meio de seu conteúdo, o público se vê representado.

Assim, a telenovela é um gênero de extrema importância para a compreensão do papel que a mídia ocupa ao representar aspectos sociais estrategicamente moldados e dirigidos ao seu público-alvo. Como já se postulou, herdou da literatura o formato do gênero folhetim, bem como aspecto estrutural melodramático. Mesmo que esteja calcada numa estrutura narrativa similar ao do folhetim, passou por várias transformações, sobretudo, por ter incorporado novas tecnologias. Hoje, consolidou-se como gênero amplamente popular e de forte aceitação por procurar cada vez mais interação com o público-alvo. Suas características melodramáticas foram substituídas por uma linguagem própria, o que propiciou contextualizar e representar os confrontos e problemas da sociedade.

\section{REFERÊNCIAS}

AGUIAR, F. Literatura, cinema e televisão. In: PELLEGRINI, T. et al. Literatura, cinema e televisão. São Paulo: Instituto Itaú Cultural, 2003, p. 115-141.

ALENCAR, M. A Hollywood Brasileira: Panorama da telenovela no Brasil. São Paulo: Senac, 2002.

BACCEGA, M. A. Narrativa Ficcional da Televisão: encontro com os temas sociais. In: Comunicação \& Educação. São Paulo: CCAECA-USP/Moderna, n. 26, jan./abr. 2003, p. 7-6. BARTHES, R. Aula. Trad. Leyla Perrone-Moisés, São Paulo: Cultrix, 1971.

BORELLI, S. H. S. Telenovelas: Padrão de Produção e Matrizes Populares. In: BRITTOS, V.C.; BOLAÑO, C.R.S. (Orgs.). Rede Globo: 40 anos de poder e hegemonia. São Paulo: Paulus, 2005.

Telenovelas Brasileiras: balanços e perspectivas. In: São Paulo em Perspectiva, São Paulo, vol. 15, n. 3, jul./set. 2001, p. 29-36. CANCLINI, N. G. Culturas híbridas. Estratégias para entrar e sair da modernidade. Trad. Ana Regina Lessa, Heloísa Pezza Cintrão e Gênese Andrade, 4. ed. São Paulo: Edusp, 2006 (Ensaios Latino-americanos, 1). 
D'ONOFRIO, S. Teoria do Texto I: Prolegômenos e teoria da narrativa. São Paulo: Ática, 1995.

HAMBURGER, E. O Brasil antenado: A sociedade da telenovela. Rio de Janeiro: Jorge Zahar, 2005.

KEHL, M. R. As novelas, novelinhas e novelóes: mil e uma noites para as multidões. In: CARVALHO, Elisabeth et al. Anos 70. Televisão. Rio de Janeiro: Edição Europa, 1980, p. 49-73. . Um só povo, uma só cabeça, uma só nação. In: CARVALHO, Elisabeth et al. Anos 70. Televisão. Rio de Janeiro: Edição Europa, 1980, p. 5-29.

KELLNER, D. A Cultura da Mídia.Estudos Culturais: Identidade Política entre o Moderno e o Pós-Moderno. Bauru: Edusc, 2001.

LOPES, M. I. V. de. Telenovela brasileira: uma narrativa sobre a nação. In: Revista Comunicação e Educação, jan./abr. 2003. Disponível em< http://www.revistas.usp.br/ comueduc/article/viewFile/37469/40183>. Acesso em 05/03/2014.

. Telenovela e direitos humanos: a narrativa de fiç̧ão como recurso comunicativo. In: ANAIS INTERCOM - Sociedade Brasileira de Estudos Interdisciplinares da Comunicação. XXXII Congresso Brasileiro de Ciências da Comunicação-Curitiba, PR -4 a 7 de setembro de 2009.

MACHADO, A. A televisão levada a sério. São Paulo: Senac, 2000.

MARTÍN-BARBERO, J.Dos meios às mediações. Comunicação, cultura e hegemonia. Trad. Ronaldo Polito e Sérgio Alcides, 2. ed. Rio de Janeiro: Editora UFRJ, 2003.

RIBEIRO, S. N.; BOTELHO, I. A televisão e o poder autoritário. In: CARVALHO, Elisabeth et al. Anos 70. Televisão. Rio de Janeiro: Edição Europa, 1980, p. 85-91.

ROCCO, M. T. F. Que pode a escola diante do fascínio da TV?. Disponível em. http:// www.crmariocovas.sp.gov.br/pdf/c ideias_09_053_a_062.pdf Acesso em 06/05/16, p. 53-62.

SADEK, J. R. Telenovela: um olhar do cinema. São Paulo: Summus, 2008.

SILVERSTONE, R. Por que estudar a mídia? São Paulo: Edições Loyola, 2002.

TÁVOLA, A. da. A telenovela brasileira: história, análise e conteúdo. São Paulo: Globo, 1996.

WOLTON, D. 0 elogio do grande público: uma teoria crítica da televisão. São Paulo: Ática, 1996.

Recebido para publicação em 06 nov. 2015. Aceito para publicação em 21 dez. 2015. 